\title{
Leisure and Tourism in the Health Concept of Women and Their Health Misconceptions
}

\author{
Zoé Mónika Lipták \\ University of Szeged, Hungary \\ Klára Tarkó \\ University of Szeged, Juhász Gyula \\ Faculty of Education, Hungary
}

\begin{abstract}
The pursuit of good health continues to be a popular pursuit in the 21st century, however not everyone understands it in the holistic sense which encompasses physical, mental, emotional, spiritual, social, and societal dimensions. Further, many do not understand how these dimensions influence their health, which leads to misconceptions and making faulty choices in healthy lifestyle practices. Leisure is strongly correlated to health and leisure activities which have been shown to have both direct and indirect effects on one's health. Research also indicates gender inequalities in leisure disadvantage women disproportionately. This paper first summarizes the understandings of misconceptions, health, leisure, tourism, and their intersections, then introduces a small sample pilot study on the health concepts and misconceptions of female university students in Hungary.
\end{abstract}

Keywords: health misconceptions, holistic health dimensions, leisure, sports, tourism

\section{Introduction}

Conceptual development is an exciting area in the cognitive sciences, particularly in the area of health. A broad understanding of what constitutes good health contributes to an individual's ability to establish and live a healthy lifestyle. Activities such as work, culture, social coexistence, consumption, education, and time management as well as leisure and how we spend our time in its associated pursuits also contribute to one's lifestyle. Choice plays an important part in our lives as we make decisions about the who, what, when, and where about our activities and the meaning that holds for us (Tarkó, 2019). Establishing a healthy lifestyle presupposes we understand the necessary underlying concepts and do not carry misconceptions that can inadvertently lead to poor lifestyle choices. For the purpose of this paper, we will look at the use of well-informed health concepts in the areas of leisure through sports and 
tourism with a focus on women in Hungary. According to Tarkó \& Benkő (2019) Hungarian women spend more time on socially constrained workload (e.g., paid work, unpaid household tasks and child rearing responsibilities) than men, and this extra time is spent at the expense of leisure, which in turn affects the health opportunities of women, their mental health status especially (Lippai \& Erdei, 2016; Tarkó, Lippai \& Benkő, 2016). We will first summarize current understandings of misconceptions, health, leisure, tourism, and their intersections. We will then introduce a small sample study on the health concepts and misconceptions of female university students in Hungary.

\section{Misconception}

As a result of changes in pedagogy and psychology, scientists have begun to address misconceptions. The most important change of this kind in the field of pedagogy is that the main goal of the school is to acquire the knowledge that can be used by pupils in everyday life (Csapó, 1998). In the field of psychology, the theory of cognitive psychology about cognition and Piaget's theory of intellectual development served as a starting point (Csapó, 1992). Cognitive psychology deals with human cognition, the way information is acquired, accessed, preserved, and retrieved. It also analyzes problem solving, comparing beginner and expert knowledge. Cognitive psychology has provided an opportunity for scientists to observe knowledge acquisition processes at different ages and at different levels of skill acquisition (Korom, 1999).

Concepts are ideas, facts or events that assist in understanding the world around us (Eggen et al., 2004).

Misconceptions is an inaccurate notion of concepts, the use of false concepts, the classification of false examples, the confusion of different concepts and the hierarchical relationships of incorrect concepts (Saputra et al., 2019, p. 1).

Misconceptions might arise from preconceptions, everyday experiences and understandings that are inconsistent with scientific or accepted explanations, or from learning oversimplified concepts (Antink-Meyer \& Meyer, 2016). Soeharto et al. (2019) noted five types: 'preconceived notions, non-scientific beliefs ..., conceptual misunderstandings, vernacular misconceptions, and factual misconceptions' (p. 248). Non-scientific beliefs emanate from sociocultural sources, such as a celebrity or a blogger, or even from family and friends. Conceptual misunderstandings are triggered from incorrect understandings and interpretation of scientific concepts. Vernacular misconceptions arise from the differences in the meanings a word has in everyday life and in science (e.g. mole denoting an animal versus a mole in chemistry denoting a unit of measurement). Factual misconceptions are misunderstandings developed in childhood but remaining until adulthood (Soeharto et al., 2019). The existence of misconceptions occurs not only in an early age, but might be present in adults teachers, educators, among others - which in turn exercises a negative effect on the elimination of misconceptions among their pupils/students (Antink-Meyer \& Meyer, 2016). 
Misconceptions or naïve ideas tend to remain stable; it is not easy to change them, they are deeply rooted and hinder knowledge acquisition (Korom, 1997, 2003). The resistance to change is due to the fact that we tend to build knowledge through experience, so it is difficult to get us to change our minds just because we are told to do so (Saputra et al., 2019). According to conceptual change theory, the individual has to experience dissatisfaction with the misconception in order to accept a new idea, and as a prerequisite, 'knowledge about the misconceptions must exist' (AntinkMeyer \& Meyer, 2016). Our literature review revealed that while there is extensive research in the area of pupil and teacher misconceptions in the natural sciences subjects (e.g., physics, chemistry, geography etc.), especially in Hungary, and while the lay health concept is also widely studied, misconceptions and health in the holistic sense were not yet linked in a research. This offers a research gap to be filled and the present study is a first step on this initiative.

\section{Health and Health Misconceptions}

Health is simultaneously a scientific and ferial category. The understanding of health underwent a paradigm change since the antiquity.

The development of sciences consequently brings a paradigm change. Paradigm change happens when the majority of scientists accept the new paradigm as the basis of further scientific activity. The new knowledge order can become institutionalised, creates its own scientific institutes, departments, journals as well as takes over the supervision of already existing ones (Benkő, 2019, p. 8.).

The starting point was a unidimensional, objective, organic, individual, and static concept based on the idea that good health was simply an absence of illness. Since the $20^{\text {th }}$ century the current approach focuses on a positive, multidimensional, subjective, personal, situational, and dynamic concept of health. Positive, because it is not about the lack of illness but about the existence of wellbeing in the holistic sense and focuses on the multiple dimensions of health like its physical (mechanistic functioning of the body), mental (the ability to think clearly and coherently), emotional (the ability to recognize emotions such as fear, joy, grief and anger and be able to properly express these emotions), spiritual (religious beliefs and practices, personal creeds, principles of behavior, ways of achieving peace of mind and being at peace with oneself), social (the ability to make and maintain relationships with other people), and societal (the effects of stimuli and phenomena in our environment) health dimensions (Naidoo \& Wills, 2009), together with the ecological well-being of the individual. It is subjective and personal, as it also matters how you experience your own health. It is situational, as health is always influenced by our living conditions. And finally, it is a dynamic process and not a state, as health is continuously changing as a prerequisite and result of active interactions between the person and his/her environment (Benkő, 2019).

Our health is influenced by a variety of factors including inherited, lifestyle, environmental, and socio-demographic factors, as well as by the operation of the health care system (Benkő, 2017; 2019) and our access to it. 
There is also a strong relationship between health status and knowledge about health (Parker, 2000), referred to as health literacy. According to the definition of the World Health Organisation (WHO), health literacy is:

the cognitive and social skills which determine the motivation and ability of individuals to gain access to, understand, and use information in ways which promote and maintain good health (Nutbeam, 1998, p. 357).

It then follows that health misconceptions may also be connected to poor health literacy.

Health misconceptions and health myths are 'distorted or false ideas about health matters' (Bedworth \& Bedworth, 2010, p. 238). Health has a subjective meaning for the general public, often full of misinterpretations, misunderstandings, and misconceptions, leading to erroneous health practices in everyday life. Most people typically correlate health to its physical dimension, depicting the healthy person as a lean, fit, and sporty individual, who follows a proper diet and rarely has to visit the doctor, leaving the mental, emotional, spiritual, social and societal aspects out. Because of this one-sided thinking, literature studies we can find deal only with physical-health related misconceptions when they study health misconceptions. For example, Zhang, Chen, and Ennis (2019) investigated students' misconceptions about energy in relation to physical activities and food intake. Their research evidence suggests that the development of a correct concept of energy requires students to acquire novel knowledge and/or abandon prior knowledge:

Naïve conceptions and misconceptions embedded in students' prior knowledge not only prevent students from assimilating new and scientifically sound knowledge, but also carry the potential of informing students to make unhealthy lifestyle related decisions (Zhang, Chen, \& Ennis, 2019, p. 35).

Olde Bekkink et al. (2016) suggest creating an inventory of the existing misconceptions within a given theme (like health), which can be disseminated among tutors, so that they can work on them with their students to improve teaching and learning.

\section{Leisure and Health}

Leisure is strongly connected to our health. Like health, leisure can also be considered holistic:

It affects our physical, mental and emotional well-being (health), promotes social integration, socialises, educates, exercises an effect on balancing sexual energies, it can be the means of expressing our identity, and its performance is connected to our natural and built environment (Benkő, 2017, p. 2).

The positive health effects of leisure are proven, especially in case of social, outdoor and hobby activities (Payne, 2002). Leisure habits, if not correctly performed or overexaggerated can, however, have negative health effects embodied in detectable 
physiological changes. E.g. leisure physical exercises chosen without proper expertise can cause physiological problems, or an everyday leisure activity, if it gains ground at the expense of other life roles, might become a symptom of psychiatric illness (e.g. video game addiction). If properly executed, leisure promotes our ability to cope with stress, while in extreme cases it can also weaken it (Benkő, 2017).

Spending leisure time is not always about maintaining or improving one's health. It is becoming more and more common to work during the holidays, which makes it difficult to fully relax and recreate. This is a kind of stress factor that can cause disease (Gilbert \& Abdullah, 2004; Marshall, 2012). The purpose of a holiday is to increase well-being and reduce stress (Neulinger, 1982; Michalkó, 2012). We cannot state that work during leisure is detrimental in the long run because this phenomenon has not yet been fully explored. In terms of body and soul, a holiday combined with work is better than a life without holiday (Nawijn \& Damen, 2014).

\subsection{Physical Activity}

In the 21st century people are increasingly health-conscious, and many identify health with physical activities and sports, thus it became a popular form of spending leisure (Lengyel et al., 2019). Regular exercising can affect all the holistic health dimensions. It contributes to reaching our potentials in physical and mental sense also, relieves stress and as an effect reduces social aggression, promotes our emotional state, strengthens family- and social bonds, and also has a significant impact on reducing juvenile delinquency through prevention programs (U.S. Department of Health and Human Services, 1996; Váczi, 2017). Physical activity reduces depression and improves the factors of metabolic syndrome (Neumann \& Frasch, 2008). Exercise also reduces brain protein damage. Injury to these proteins is part of the natural process of advancing age (Radák et al., 2001). When brain proteins are damaged, brain functions decline (Carney et al., 1991). In their research Pikó and Keresztes (2007) claimed that sports have a positive effect in terms of obesity prevention, cardiovascular function, skeletal system, support system, type II diabetes etc. When doing sports, the individual feels better. Young people who exercise regularly feel fitter and stronger, resulting in greater satisfaction with their appearance, which also affects other areas of their lives, such as self-image (Kopp \& Martos, 2011). In addition, sport also creates a milieu for socialization (Pikó \& Keresztes, 2007). There also exists a global health initiative called 'Exercise is Medicine' (see: https://www.exerciseismedicine.org/). Be aware though, that excessive hard training and excessive focus on training can lead to the emergence of sports addiction, which has recently been considered a new disorder (Rendi et al., 2010). In the case of sports addiction, the individual spends more and more time on training, neglects his or her family and social life, and his or her often irresponsible behaviour increases the possibility of injury also (Demetrovics \& Kurimay, 2008). In summary, with regular, normal intensity (up to 30 minutes a day) activity and training, we do more for our health than if we do not or overdo sport or exercise. 
Some people use sports and exercising exclusively for shaping their bodies and maintaining (Hill et al., 2012), or losing their weight. Several studies demonstrate, however, that physical activity in itself is not enough to lose weight (Wing, 1999; Thorogood et al., 2011), it is also essential to pay attention to nutrition in terms of quality and quantity as well, which depends on our health status and the degree of our physical activity (Tihanyi, 2016).

\section{Health, Physical Activity, and Tourism}

'Tourism is travel to a destination (involving an overnight stay and at least 24 hours stay away from home) which incorporates leisure and recreation activities' (Page \& Connell, 2020, p. 7). Mason (2020) lists 11 motivations or reasons to travel: 1. escape, 2. relaxation, 3. play, 4. strengthening family bonds, 5 . prestige, 6 . social interactions, 7. sexual opportunity, 8. self-fulfilment, 9. wish fulfilment, 10. shopping (p. 8). An other categorisation could be tourism for pleasure (leisure, culture, active sports, visiting friends and relatives), professional tourism (meetings, missions, business), and leisure for other purposes (study, health, transit) (Mason, 2020). From among the different motivation areas we will discuss sport tourism and health tourism.

\section{Sport Tourism and Health Tourism}

Although sport and tourism are two different areas, their intersection or synergy called sport tourism is becoming more widespread (Győri, 2015; Melo \& Sobry, 2017). Gibson (1998) has made a literature study on the definitions of sport tourism, and noticed three distinct behaviour types associated with sport tourism: '(1) actively participating (Active Sport Tourism), (2) spectating (Event Sport Tourism), and (3) visiting and, perhaps, paying homage (Nostalgia Sport Tourism)' (p. 49). So, she concluded the following comprehensive definition stating sport tourism is 'leisurebased travel that takes individuals temporarily outside of their home communities to play, watch physical activities or venerate attractions associated with these activities' (Gibson, 1998, p. 49). Higham and Hinch (2018) gave an overview on a fourfold classification of sport tourism, covering: 1 . spectator events, where the number of spectators is large (e.g. Olympic Games, F1, etc.), 2. Participation events, where the number of competitors is large, and the number of spectators is negligible (e.g. amateur or recreational sports events), 3. Active engagement in recreation sports, and 4. Sports heritage and nostalgia (e.g. visiting attractions like sport museums, halls of fame etc.).

Smith and Puczko (2014) state that health tourism:

comprises those forms of tourism which are centrally focused on physical health, but which also improve mental and spiritual well-being and increase the capacity of individuals to satisfy their own needs and function better in their environment and society (p. 206).

There are three different but overlapping sectors of health tourism, which are medical, wellness and spa tourism. In case of medical tourism medical treatments, 
interventions or therapies are in the focus of travelling. Wellness tourism addresses prevention and personal well-being. Spa tourism is undertaken with the aim of healing, relaxation or beautifying the body (Hodžić \& Paleka, 2018).

\section{Unequal Leisure, Health, and Tourism Opportunities}

Opportunities for leisure, health, and tourism are not equal for everyone, but depend on one's place of residence (type of settlement and the living environment within, region within a country, country, continent); race/ethnicity (e.g. Romany, AfroAmerican); occupation (e.g. miner vs. university professor); gender (man or woman); religion; level of education; socio-economic status; and social capital/resources (Vitrai et al., 2008). From the present chapter's point of view the gender differences will be discussed.

Gender is a decisive factor in leisure trends, especially when it comes to time available for leisure (Tarkó, 2004, 2016; Ferencz \& Tarkó, 2016). Yerkes et al. (2020) made a cross-national comparison in 36 countries concerning gender differences in the quality of leisure. They concluded that there were gender differences in leisure quality across countries:

in countries with conservative gender norms, low levels of childcare coverage, limited paternity leave and lower political power for women, women's leisure quality is lower than men's (Yerkes et al., 2020, p. 379).

Women perform their social responsibilities (paid work, household work, childbearing, taking care for the elderly parents or sick relatives) at the expense of quality leisure (Henderson \& Gibson 2013). Tarkó and Benkő (2019) examined the daily activity structure of men and women in Hungary, where time budget surveys are conducted in every 10 years since 1963. Survey data are categorised into 3 sections: 1. total workload/constrained time, 2. personal needs, and 3. free time/leisure. Through the secondary statistical analysis of these sections by genders the researchers have proven the increased workload (constrained time) for women, and the decrease in time spent on leisure. The average reported leisure time spent on sports and physical exercises was generally low in Hungary, especially in the case of women, and women on maternity leave and housewives, as well as those with low and mid-level education (Tarkó \& Benkő, 2019). However, women walk more as a leisure activity than men (Pollard \& Wagnild, 2017; Tarkó \& Benkő, 2019). Extended workload and less time for leisure can lead to mental health problems (Tarkó et al., 2016).

The Global Report on Women in Tourism - Second Edition (World Tourism Organisation, 2019) provided information about women in the tourism sector, based on data coming from 157 countries. Among the key findings were mentioned, that $54 \%$ of those employed in tourism are women, but in a low-level employment, there are high staff turnover, long working hours, subcontracting, flexible working conditions, the prevalence of casual workers and seasonal variations in employment 
and the majority of women's work is concentrated in seasonal, part-time, low-paid and low-skill activities, such as retail hospitality and cleaning; and there is a gender pay gap: women earn $14 \%$ less than men (World Tourism Organisation, 2019, pp. 3435).

\section{Health, Health Misconceptions, Sports, and Tourism - An Empirical Research}

We have studied the health concept and health misconceptions of higher education students studying on educational, sociological and health sciences professional domains in Hungary. The results of this research are presented in the followings to illustrate how people think about health and how leisure focusing on sports and tourism is depicted among the personal health factors. The present research is the first stage of a future large-scale survey on the health misconceptions of future educators.

\section{Methods}

The sample consisted of 68 participants, out of which only 5 respondents were men. Given the perspective of this chapter, only the data of female participants was analysed $(n=63)$. The anonymous, self-administered questionnaire contained openended questions referring to the participants' understanding of health, as well as multiple-choice questions on health misconceptions, together with background sociodemographic questions. Data analysis was done with the help of the SPSS25.0 statistical package. While the scope of the study went beyond leisure, only those results relevant to leisure were selected.

\section{Results}

The understanding of health was measured through respondents' imaginary picture of how they view health. Answers to this open-ended question were then categorised along the 6 dimensions of holistic health: physical, mental, emotional, spiritual, social and societal (Table 1.).

Table 1. Presentation of the dimensions of the holistic health concept $(n=63)$

\begin{tabular}{|l|l|}
\hline Holistic health dimensions & Rate of presenting on the pictures (\%) \\
\hline Physical & 94.8 \\
\hline Emotional & 32.8 \\
\hline Social & 17.2 \\
\hline Spiritual & 10.3 \\
\hline Mental & 8.6 \\
\hline Societal & 1.7 \\
\hline
\end{tabular}

Results revealed that from the holistic health dimensions the predominance of the physical health dimension characterises the respondents' perceptions of health 
$(94,8 \%)$. We have examined the actual content of what physical health meant for those women, who indicated such a dimension (Table 2.).

Table 2. The content of the physical dimension in case of those, who indicated it $(\mathrm{n}=55)$

\begin{tabular}{|l|l|}
\hline $\begin{array}{l}\text { Elements of the physical health } \\
\text { dimension }\end{array}$ & $\begin{array}{l}\text { Rate of presenting on the pictures } \\
(\%)\end{array}$ \\
\hline Nutrition & 54.5 \\
\hline Sports & 38.2 \\
\hline Body & 25.5 \\
\hline Nature & 18.2 \\
\hline
\end{tabular}

In the physical dimension we found nutrition to be the most predominant $(54.5 \%)$, followed by doing sports (38.2\%). The body (25.5\%) and nature (18.2\%) were less emphasized.

We have also analysed the health pictures considering whether they depict some kind of a leisure activity or not. Leisure activity was depicted in $39.7 \%$ of respondents (23 respondents). Four women (17.4\%) out of these 23 mentioned excursions in nature, which can be associated with tourism, while there were 20 mentions (87.0\%) of a sport or physical activity, running mainly. One respondent could have multiple purposes, that is why the percentages add up more than $100 \%$.

Leisure is a very important element of our lifestyle, and lifestyle contributes to our health in 43\% (Lalonde, 1974). We have asked respondents to distribute 100 health points among lifestyle, genetics, environmental effects, and health care, estimating their importance in terms of their health (Table 3.).

Table 3. Factors influencing health $(n=58)$

\begin{tabular}{|l|l|l|}
\hline & \% (own research) & $\%$ (literature) \\
\hline Lifestyle & $42.4 \%($ SD: 15.9$)$ & $43 \%$ \\
\hline Genetics & $24.7 \%($ SD: 16.2$)$ & $27 \%$ \\
\hline Environmental effects & $20.5 \%(S D: 9.2)$ & $19 \%$ \\
\hline Health care system & $13.5 \%(S D: 7.4)$ & $11 \%$ \\
\hline
\end{tabular}

Looking at the sample mean, our respondents correctly considered lifestyle playing the most important role in the promotion of their health 42.4\% (SD: 15.9). The mean was slightly higher (42.6) for those respondents, who depicted a leisure activity in their imaginary picture on health (the mean was 41.2 for those, who did not), however the differences are not significant.

To measure health misconceptions, we have listed 40 health statements found in the literature to be the most common health misconceptions. The statements referred mostly to nutrition, obesity, diabetes, smoking, alcohol consumption, hygiene, but 
there were also two statements referring to sports. There were no tourism-related misconceptions mentioned in the literature. Respondents had to express their opinions concerning these statements on a 5-points Likert scale $(1=$ not true at all, $2=$ not true, $3=$ partially true, $4=$ true, $5=$ completely true). The two sports related statements were: 1 . 'If I exercise enough, I do not have to take care of the amount of what I eat' (mean $=1,85$, median $=2,00$, modus $=2$ ) and 2 . 'The more hard I exercise, the more I do for my health' (mean=3,03, median=3,00, modus=3). The central tendency indices indicate a misconception in case of the 2 nd statement, as respondents identify over-exercising with good health.

\section{Summary and Conclusion}

Due to the low sample size of our present measurement, we could not perform the analysis according to the background variables. With the help of the measurement tool we found that the physical dimension dominated in the responding women's concept of health (94.8\%), the appearance of the emotional dimension was the second most frequent mention (32.8\%), and the social dimension was the third most frequently mentioned (17.2\%), the spiritual one (10.3\%), the mental one (8.6\%) were very low, and the social dimension barely appeared (1.7\%). All this is a good indication of the lack of a holistic interpretation of the concept of health. Nutrition was the most often presented (54.5\%) element among the physical health factors, followed by sports (38.2\%). Leisure activities were mentioned in $39,7 \%(n=23)$, out of which four women wrote about excursions in nature. Tourism was not directly mentioned, but we can associate it with excursions to nature, and everything the participants did for their health and physical fitness could be part of sport and health tourism activities. These are only presumptions, as participants have not mentioned the circumstances or context of their actions.

In the present study, the respondents already had detectable health misconceptions. From among the 40 health statements listed in the questionnaire two referred to sports and there were none referring to tourism, as the literature search did not bring results in this respect. Respondents identified over-exercising with good health, which is clearly a misconception and could be a dangerous practice in terms of our health. In order to examine health misconceptions more accurately, we consider it necessary to restructure the listed health misconceptions and to state some of them more clearly.

A limitation of the study was that we found statements in the literature predominantly regarding the physical health dimension. This may also indicate that the presence of the physical dimension is most active in people's thinking about health. However, it may also mean that the study of health-related misconceptions has so far focused only on the physical dimension, so misconceptions about other dimensions have not been examined, although there are many. Another task of our research will be to uncover misconceptions about all six dimensions of health and 
connect them to the different sectors, such as tourism, when client motivations are studied.

Depending on the results of the pilot, we intend to carry out our restructured questionnaire in Hungarian higher education institutions with the participation of students in teacher education. We expect a total of 1000 participants. Our analyses will be carried out using the SPSS statistical software package. As a further step in our research, we aim to interview head teachers about their misconceptions about health.

Studying the health concept, the health misconceptions and their sources is an important prerequisite if we would like to achieve positive change in people's lifestyle practices. It is also very important to study them among future teachers, as educators have an immediate effect on the health concept and lifestyle practices of children and young people.

\section{References}

[1] Antink-Meyer, A. \& Meyer, D. Z. (2016). Science Teachers' Misconceptions in Science and Engineering Distinctions: Reflections on Modern Research Examples. Journal of Science Teacher Education, 27, 625-647. https://doi.org/10.1007/s10972-016-9478-z

[2] Bedworth, D. A. \& Bedworth A. E. (2010). Dictionary of Health Education. Oxford University Press.

[3] Benkő, Zs. (2017). Healthy Leisure and Leisureful Health: Introductory 'State of the Art'. In: Zs. Benkő, I. Modi \& K. Tarkó (Eds.), Leisure, Health and WellBeing: A Holistic Approach (pp. 1-8). Palgrave Macmillan.

[4] Benkő, Zs. (2019). Homo Sanus: Culture, Leisure and Spirituality as its's important manifestation in people's lifestyle. DOCERE 1(1-2), 3-12.

[5] Carney, J. M., Starke-Reed, P. E., Oliver, C. N., et al. (1991). Reversal of agerelated increase in brain protein oxidation, decrease in enzyme activity, and loss in temporal and spatial memory by chronic administration of the spintrapping compound N-tert-butyl-alpha-phenylnitrone. Proceedings of the National Academy of Sciences $U$ S A, 88(9), 3633-3636. https://doi.org/10.1073/pnas.88.9.3633

[6] Csapó, B. (1992). Kognitív pedagógia. (Cognitive Pedagogy). Akadémiai Kiadó.

[7] Csapó, B. (1998). Az iskolai tudás. (School-related Knowledge). Osiris Kiadó.

[8] Demetrovics, Zs. \& Kurimay, T. (2008). Testedzésfüggőség: a sportolás mint addikció (Exercise addiction: sports as addiction.). Psychiatria Hungarica, 23, 129-141.

[9] Eggen, P. \& Kauchak, D. (2004). Educational Psychology: Windows, Classrooms. Pearson/Merill Prentice Hall.

[10] Ferencz, K. \& Tarkó, K. (2016). Nők - iskola - esélyegyenlőség (Women School - Equal Opportunities). In: K. Tarkó \& Zs. Benkő (Eds.), "Az egészség nem egyetlen tett, hanem szokásaink összessége": Szemelvények egy 
multidiszciplináris egészségfejlesztő mühely munkáiból. (Health is not a unique act, but it is the totality of our habits. Excerpts from the work of a multidisciplinary health promotion workshop.) (pp. 233-247). Szegedi Egyetemi Kiadó, Juhász Gyula Felsőoktatási Kiadó.

[11] Gibson, H. J. (1998). Sport tourism: a critical analysis of research. Sport Management Review, 1(1), 45-76.

[12] Gilbert, D. \& Abdullah, J. (2004). Holidaytaking and the Sense of Well-being. Annals of Tourism Research. 31(1), 103-121. https://doi.org/10.1016/j.annals.2003.06.001

[13] Győri, F. (2015). Sport tourism. In: M. Domokos, P. Dorka, F. Győri \& G. Kiss (Eds.), Recreation I. University of Szeged, Juhász Gyula Faculty of Education, Institute of Physical Education and Sports, Szeged. Retrieved April 2, 2020, from http://eta.bibl.u-szeged.hu/1261/2/rekreacio_I_angol/index-2.html

[14] Henderson, K. A. \& Gibson, H. J. (2013). An integrative review of women, gender, and leisure: Increasing complexities. Journal of Leisure Research, 45(2), 115-135. https://doi.org/10.18666/jlr-2013-v45-i2-3008

[15] Higham, J. \& Hinch, T. (2018). Sport Tourism Development. Channel View Publications.

[16] Hill, J. O., Wyatt, H. R. \& Peters, J. C. (2012). Energy balance and obesity. Circulation, 126(1),

126-132. https://doi.org/10.1161/CIRCULATIONAHA.111.087213

[17] Hodžić, S. \& Paleka, H. (2018). 'Health Tourism in the European Union: Financial Effects and Future Prospects'. In: 9th International Conference of the School of Economics and Business Conference Proceedings. pp. 162-174.

[18] Kopp, M. \& Martos, T. (2011). A társadalmi összjóllét jelentősége és vizsgálatának lehetőségei a mai magyar társadalomban I. Életminőség, gazdasági fejlődés és a nemzeti összjólléti index. (The significance of social well-being and the possibilities of its examination in today's Hungarian society I. Quality of life, economic development and the national well-being index.) Mentálhigiéné és Pszichoszomatika, 3, 241-259. https://doi.org/10.1556/Mental.12.2011.3.3

[19] Korom, E. (1997). Naiv elméletek és tévképzetek a természettudományos fogalmak tanulásakor (Naive theories and misconceptions when learning science concepts). Magyar Pedagógia, 97(1), 19-40. http://www.magyarpedagogia.hu/document/196.pdf

[20] Korom, E. (1999). A naiv elméletektől a tudományos nézetekig. (From Naive Theories to Scientific Views). Iskolakultúra, 9(10), 60-71.

[21] Korom, E. (2003). A fogalmi váltás kutatása (Research of conceptual change). Iskolakultúra, 8 , 84-94. http://real.mtak.hu/60604/1/EPA00011_iskolakultura_2003_08_084094.pdf

[22] Lalonde, M. (1974). A New Perspective on the Health of Canadians. Minister of Supply and Services, Ottawa, Ontario, Canada. 
[23] Lengyel, A., Mórik, V .K. \& Molnár, A. (2019). Könyvajánló: sport és turizmus 2015 (Book recommendation: sports and tourism 2015). Acta Carolus Robertus, 9(1), 145-155. http://real.mtak.hu/98856/1/145_155_Lengyel.pdf

[24] Lippai, L. L. \& Erdei, K. (2016). Lelki egészségfejlesztő programok előkészítése városi szinten - a hódmezővásárhelyi lelki egészségfelmérés elemzésének tanulságai. (Preparation of Mental Health Promotion Programmes on a City Level - Lessons Learnt from a Mental Health Promotion Research in Hódmezővásárhely). In. K. Tarkó \& Zs. Benkő (Eds.): „Az egészség nem egyetlen tett, hanem szokásaink összessége” Szemelvények egy multidiszciplináris egészségfejlesztô mühely munkáiból. (Health is not a unique act, but it is the totality of our habits. Excerpts from the work of a multidisciplinary health promotion workshop.) (pp. 111-126). Szegedi Egyetemi Kiadó, Juhász Gyula Felsőoktatási Kiadó.

[25] Marshall, J. (2012). Legal Opinion: Working while on Holiday. Personnel Today, DVV Média International. Retrieved April 14, 2020, from http://www.personneltoday.com/hr/legal-opinion-working-while-onholiday/

[26] Mason, P. (2020). Tourism Impacts, Planning and Management, 4th Edition. Routledge.

[27] Melo, R. \& Sobry, C. (2017, Eds.). Sport Tourism. Cambridge Scholars Publishing.

[28] Michalkó, G. (2012). Turizmológia (Tourismology). Akadémiai Kiadó.

[29] Naidoo, J. \& Wills, J. (2009). Foundations of Health Promotion. Baillière Tindall.

[30] Nawijn, J. \& Damen, Y. (2014). Work during Vacation: Not so Bad after All. Tourism Analysis, 19(6), 759-767. http://dx.doi.org/10.3727/108354214X14146846679565

[31] Neulinger, J. (1982). Leisure lack and the quality of life: The broadening scope of the leisure professional. Leisure Studies, 1, 53-64. https://doi.org/10.1080/02614368200390051

[32] Neumann, N. U. \& Frasch, K. (2008). Coherences between the metabolic syndrome, depression, stress and physical activity. Psychiatrische Praxis, 36(3), 110-114. DOI: 10.1055/s-2008-1067558

[33] Nutbeam, D. (1998). Health promotion glossary. Health Promotion International, 13, 349-364. https://doi.org/10.1093/heapro/13.4.349

[34] Olde Bekkink, M., Donders, A. R. T. R., Kooloos, J.G. et al. (2016). Uncovering students' misconceptions by assessment of their written questions. $B M C$ Medical Education, 16, 221-227. https://doi.org/10.1186/s12909-0160739-5

[35] Page, S. J. \& Connell, J. (2020). Tourism: A Modern Synthesis, 5th Edition. Routledge. 
[36] Parker, R. (2000). Health literacy: a challenge for American patients and their healthcare providers. Heath Promotion International, 15(4), 277-283. https://doi.org/10.1093/heapro/15.4.277

[37] Payne, L. L. (2002). Progress and Challenges in Repositioning Leisure as a Core Component of Health. Journal of Park and Recreation Administration, 20(14), 1-11. https://js.sagamorepub.com/jpra/article/view/1526

[38] Pikó, B. \& Keresztes, N. (2007). Sport, lélek, egészség (Sport, spirit, health). Akadémiai Kiadó.

[39] Pollard, T. M. \& Wagnild, J. M. (2017). Gender Differences in Walking (for Leisure, Transport and in Total) Across Adult Life: A systematic Review. BMC Public Health, 17, 341-347.http://doi.org/10.1186/s12889-017-4253-4

[40] Radák, Z., Kaneko, T., Tahara, S., Nakamoto, H. et al. (2001). Regular exercise improves cognitive function and decreases oxidative damage in rat brain. Neurochemistry International, 38, 17-23. DOI: 10.1016/s01970186(00)00063-2

[41] Rendi, M., Szabó, A. \& Bárdos, Gy. (2010). Testedzésfüggőség: Egy ritka, de súlyos pszichológiai rendellenesség (Exercise Dependence: A rare but serious psychological disorder). Magyar Pszichológiai Szemle, 65(3), 529544. https://doi.org/10.1556/mpszle.65.2010.3.4

[42] Saputra, O., Setiawan, A. \& Rusdiana, D. (2019). Identification of student misconception about static fluid. Journal of Physics: Conference Series, 1157(3), 1-6. https://doi.org/10.1088/1742-6596/1157/3/032069

[43] Smith, M. K. \& Puczkó, L. (2014). Health, Tourism and Hospitality: Spas, Wellness and Medical Travel. Routledge.

[44] Soeharto, S., Csapó, B., Sarimanah, E., Dewi, F. I. \& Sabri, T. (2019). A Review of Students' Common Misconceptions in Science and their Diagnostic Assessment Tools. Jurnal Pendidikan IPA Indonesia, 8(2), 247-266. https://doi.org/10.15294/jpii.v8i2.18649

[45] Tarkó, K. (2004). Gender Roles in the Society; the State of Women. In: K. Tarkó (Ed.), Multicultural Education. (pp. 75-84). Juhász Gyula Felsőoktatási Kiadó.

[46] Tarkó, K. (2016). A sokszínű társadalom - kisebbségi csoportok Magyarországon. (A colourful society - minority groups in Hungary) In: K. Tarkó \& Zs. Benkő (Eds.), 'Az egészség nem egyetlen tett, hanem szokásaink összessége': Szemelvények egy multidiszciplináris egészségfejlesztő mühely munkáiból. (Health is not a unique act, but it is the totality of our habits. Excerpts from the work of a multidisciplinary health promotion workshop.) (pp. 67-77). Szegedi Egyetemi Kiadó, Juhász Gyula Felsőoktatási Kiadó.

[47] Tarkó, K., Lippai, L. \& Benkő, Zs. (2016). Evidence-Based Mental-Health Promotion for University Students - A Way of Preventing Drop-Out. TOJET: Turkish Online Journal of Educational Technology, Special Issue for IETC, ITEC, IDEG, ITICAM 2016, 261-268. http://www.tojet.net/special/2016_7_1.pdf. 
[48] Tarkó, K. (2019). Életmódról tudományosan a mindennapokban (About everyday lifestyle, in scientific terms). In. Zs. Benkő, L. Lippai \& K. Tarkó (Eds.), Az egészség az életünk tartópillére. Egészségtanácsadási kézikönyv. (Health is the pillar of our life. Health counselling handbook). (pp. 79-89). Szegedi Egyetemi Kiadó, Juhász Gyula Felsőoktatási Kiadó.

[49] Tarkó, K. \& Benkő, Zs. (2019). Unequal leisure opportunities across genders - overwhelmed women. International Journal of the Sociology of Leisure, 2(12), 7-26. https://doi.org/10.1007/s41978-018-00025-9

[50] Thorogood, A., Mottillo, S., Shimony, A., Filion, K.B. et al. (2011). Isolated aerobic exercise and weight loss: a systematic review and meta-analysis of randomized controlled trials. American Journal of Medicine, 124(8), 747-755. DOI: 10.1016/j.amjmed.2011.02.037

[51] Tihanyi, A. (2016). Sportágspecifikus sporttáplálkozás (Sports-specific sports nutrition). Krea-Fitt Kft.

[52] U.S. Department of Health and Human Services (1996). Physical Activity and Health: A Report of the Surgeon General. Atlanta, GA: U.S. Department of Health and Human Services, Centers for Disease Control and Prevention, National Center for Chronic Disease Prevention and Health Promotion, Retrieved December 5, 2020, from https://www.cdc.gov/nccdphp/sgr/pdf/sgrfull.pdf

[53] Váczi, P. (2017). Marketing és menedzsment módszerek a kosárlabda sportágban az Észak- magyarországi és Észak- alföldi régiókban (Marketing and management methods in basketball in the regions of Northern Hungary and the Northern Great Plains). PhD dissertation. Debreceni Egyetem.

[54] Vitrai, J., Hermann, D., Kabos, S., Kaposvári, Cs. et al. (2008). Egészségegyenlőtlenségek Magyarországon. Adatok az ellátási szükségletek térségi egyenlötlenségeinek becsléséhez. (Health inequalities in Hungary. Data for estimating regional disparities in supply needs). Data EgészségMonitor, Budapest, Hungary.

[55] Wing, R. R. (1999). Physical activity in the treatment of the adulthood overweight and obesity: current evidence and research issues. Medicine \& Science in Sports \& Exercise, 31(11 Suppl), S547-552. DOI 10.1097/00005768-199911001-00010

[56] World Tourism Organization (2019). Global Report on Women in Tourism, Second Edition. UNWTO, Madrid, Spain. Retrieved April 2, 2020, from https://doi.org/10.18111/9789284420384

[57] Yerkes, M. A., Roeters, A. \& Baxter, J. (2020). Gender differences in the quality of leisure: a cross-national comparison. Community, Work \& Family, 23(4), 367-384. https://doi.org/10.1080/13668803.2018.1528968

[58] Zhang, T., Chen, A \& Ennis, C. (2019). Elementary school students' naïve conceptions and misconceptions about energy in physical education context. Sport, Education and Society, 24(1), 25-37. DOI https://doi.org/10.1080/13573322.2017.1292234 